\title{
The Impact of Corporate Social Responsibility (CSR) on National and International Corporations Prevailing in Bangladesh: A Comparison of CSR on the Basis of Carroll's Pyramid
}

\author{
Afzal Hossain, Kazi Abul Bashar, Behzad Noor \\ Department of Business Administration, Shanto-Mariam University of Creative Technology, Uttara, Dhaka, Bangladesh \\ Email address: \\ aafxal_005@yahoo.com (A. Hossain), kaziabulbashar@yahoo.com (K. A. Bashar), Bnoorphil15@gmail.com (B. Noor) \\ To cite this article: \\ Afzal Hossain, Kazi Abul Bashar, Behzad Noor. The Impact of Corporate Social Responsibility (CSR) on National and International \\ Corporations Prevailing in Bangladesh: A Comparison of CSR on the basis of Carroll's Pyramid. Journal of Investment and Management. \\ Vol. 6, No. 1, 2017, pp. 6-12. doi: 10.11648/j.jim.20170601.12
}

Received: August 30, 2016; Accepted: September 28, 2016; Published: November 23, 2016

\begin{abstract}
This research paper examines how the National and International companies manage Corporate Social Responsibility (CSR) in Bangladesh. It considers how the concept has come to be framed within business in Bangladesh, which is increasingly globalized. In looking at how CSR practices are being adopted and adapted by National and International companies in Bangladesh, we can begin to see what implications arise from the fact that CSR is a Western-led concept and Bangladesh can be thought to be lagging behind in its understanding and adoption of CSR as companies do not necessarily state their policies in such a formal extent that is expected. The study comprises the impact of CSR of the National and International corporations on the basis of Carroll's pyramid. In this study we have considered two companies for making comparisons; one is SQUARE Bangladesh Ltd. as the national company and another is Unilever Bangladesh Ltd. as the multinational company.
\end{abstract}

Keywords: CSR, Carroll Pyramid, SQUARE Bangladesh Ltd, The Unilever Bangladesh Limited

\section{Introduction}

'Corporate Social Responsibility' or CSR for short is a somewhat new term that has rapidly gained momentum. Hundreds, indeed thousands of companies are adopting 'ethical policies' or 'codes of conduct' saying how they intend to behave. More and more companies are signing up to such initiatives as the United Nations Global Compact or the Fair Labor Association. They are joining bodies like World Business Council for Sustainable Development and CSR Europe. [1]

Apart from the generous social services by some business firms, the new concept of CSR is a rising one. Businesses are driven by governments, labor unions consumer groups and other stakeholders of the society and they all by consider CSR as a long time investment. Globalization has made CSR practice an essential part of Bangladesh business. CSR focuses on the benefits of all stakeholders. International business has grown so rapidly in the past decade that may experts believe we are living in the era of globalization. But the overall status of CSR in Bangladesh is still very inadequate. Lack of Good Governance, absence of strong labor unions or consumer rights group not so viable and inability of the business community to perceive CSR as a survival pre-condition for export and private investment. Some untoward incident like boycott from the importer has taught the local business community about the enormous importance of CSR. [1]

CSR is a concept whereby companies integrate social and environmental concerns in their business operations and in their interactions with their stakeholders on a voluntary basis [2]. Socially responsibility means not only fulfilling legal expectations, but also going beyond compliance and investing 'more' into human capital, the environment and in rapport-building with stakeholders. It is relevant in all types of companies and in all sectors of activity, from MSMEs to Multinational Enterprises (MNEs). "A number of companies 
with good social and environmental records indicate that these activities can result in better performance and can generate more profit and growth [2]. Research has shown that about one half of the above average performance of socially responsible companies can be attributed to their CSR image while the other half is explained by their performance (Industry week, 2001). Socially responsible companies are expected to deliver above-average financial returns [2]. CSR has some internal dimensions such as: human resources management, health and safety at work, adaptation to change and management of environmental impact and natural resources. The external dimensions include local communities, business, partners, suppliers and consumers, human rights and global environmental concerns. Again, CSR may be as simple as sponsoring social service oriented entertainment events. In essence, 'CSR is positive rapport with the society'. In a Bangladesh context, several multinational companies and local companies practice CSR. While the multinationals are influenced by their own ESRB disposition, most of the business concerns in Bangladesh do not rate high in practicing CSR unless being pressured by the foreign buyers in case of export oriented business. [1].

\section{Review of Literature}

A literature review of research was carried out to put light into the definition of Corporate Social Responsibility (CSR) as this differs from country to country and different authors have modeled different definition for CSR.

In the book 'Corporate Social Responsibility' by Crowther D and Aras G, Milton Friedman stated that "There is one and only one social responsibility of business- to use its resources and engage in activities designed to increase its profits so long as it stays within the rules of the game, which is to say, engages in open and free competition without deception or fraud" [3]

According to Friedman's (1970) theory, the sole responsibility of the business is to capitalize profit. [10]

According to Friedman (1970 cited in Galbreath 2009, p. 111 ), it is the firm responsibility to meet the economic needs and that only leads to the welfare of the society and it is the role of the government, service organization, educational institution to meet the societal welfare. [4]

Carroll's (1979) model conceptualizes the responsibilities of the firm are as:

a. the economic responsibility to generate profits;

b. the legal responsibility to comply by local, state, federal, and relevant international laws;

c. the ethical responsibility to meet other social expectations, not written as law (e.g. avoiding harm or social injury, respecting moral rights of individuals, doing what is right, just, fair); and

d. the discretionary responsibility to meet additional behaviors and activities that society finds desirable (e.g. philanthropic initiatives such as contributing money to various kinds of social or cultural enterprises). [5]

The last concept applies to the Mauritian context where
NGOs are engaged in the philanthropic activities. They are funded by firms making profit and $1 \%$ of the profit after tax is given to the NGOs to look at the vulnerable groups in Mauritius, the other $1 \%$ goes to the contribution of programs offered by government, (NEF, 2008).

The economics needs of the firm are met to comply with CSR (NEF, 2008). The firm has to contribute $2 \%$ of its profit after tax in the CSR fund. If the firms make no profit then there is no contribution to CSR.

\section{Objectives of the Study}

CSR as a concept is being gradually interwoven into the psyche of local business, however, the process is slow and only in its infancy. The primary and most important benefit from implementing mechanisms such as a code of corporate governance is likely to be felt at the national level with an improved global perception of Bangladeshi business procedures including improved ethical business practices. In turn, this could lead to a process of revitalization of the Bangladeshi economy [6].

As it has been noted earlier that the main objective of this research is to find out overall impact of CSR on National and International company of Bangladesh in perspective of global concern with the help of Carroll pyramid, specifically the major objectives of the study could be pointed out as:

a. To examine and compare how CSR is perceived by National and International Concerns in Bangladesh.

b. To describe and explain the overall comparison of CSR regarding National and International perspective.

c. To conceptualize the CSR concept of a multinational company.

d. To see the significance of CSR reporting in International business.

e. To focus the overall CSR position

\section{Sources of Data}

The study is based on the research which is qualitative by nature. Physical inspection of the two selected companies' CSR activities was the main primary sources of data for the present study. Along with the primary sources there are some secondary data source as Annual CSR Report, Fact Files and Companies' Websites. In this research after collecting the relevant information from the aforesaid sources of the two studied National (i.e., SQUARE Bangladesh Ltd) and Multinational (i.e., Unilever Bangladesh Ltd.) companies, the information are analyzed on the basis of theoretical judgment upon the assembled material availing the principles of "Carroll's Pyramid".

\section{Analysis and Interpretation}

Corporate Social Responsibility (CSR) involves the conduct of a business so that it is economically profitable, law abiding, ethical and socially supportive. To be socially responsible the means that profitability and obedience to the 
law are foremost conditions when discussing the firm's ethics and the extent to which it supports the society in which it exists with contributions of money, time and talent [5]. And the different layers in the pyramid help to see the different types of obligations that society expects of businesses.

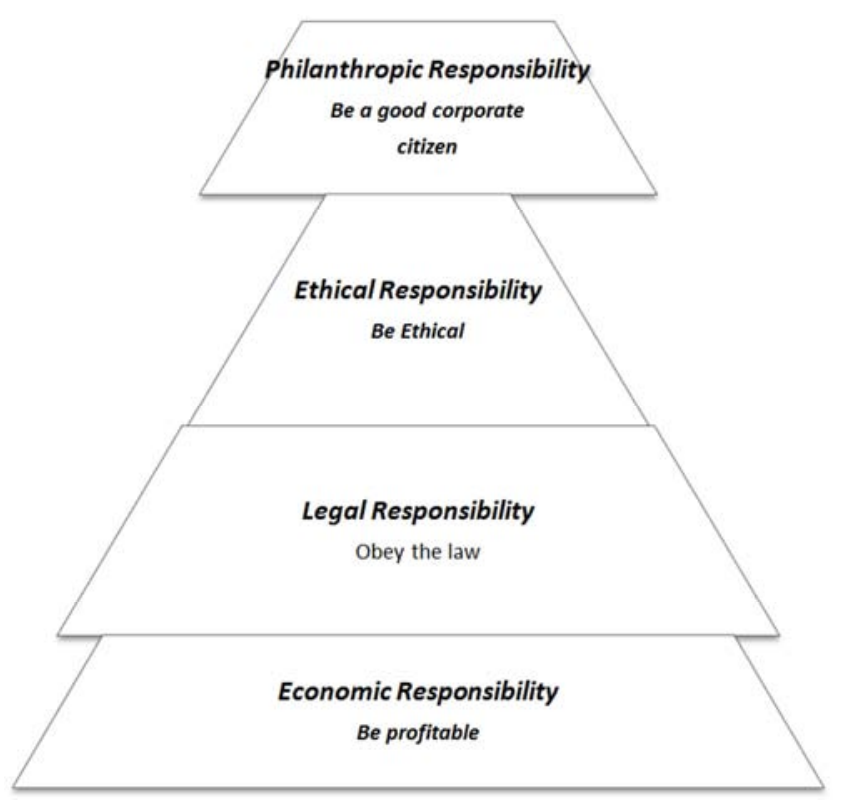

Figure 1. Carroll's Pyramid.

\subsection{Economic Responsibility}

Economic responsibility means ensuring that there is an economic benefit both to the region from which the purchase came and to the region in which it is marketed. Is the process economically fair to everyone involved? Is anyone being exploited? Can production be done at a price that people can afford?

So this is also a CSR issue, by supporting this (i.e. figure 1); Economic responsibilities denote the maximization of companies values. Companies are required to maximize their shareholders' earnings. This is done by producing goods and services that are in demand in the market. [5]

\subsection{Legal Responsibility}

A Business's role in causing an event to happen, a chain of causation means business is responsible for an event. This is fraction of the law of legal liability and public liability. Now businesses are considered as a corporate citizen that complies with the act and set of laws broadcasted by central status and local governments. Legal responsibilities are those that are defined by the authorities and companies are required to abide by them in a strict and disciplined manner. These laws and regulations (i.e. mention in figure 1) are the ground on which businesses must operate. Legal responsibilities embody indispensable notions of "fair operations as established by our lawmakers". Even though they are depicted as the after that level of the pyramid it is seen synchronized with the economic one. In other words maximizing ones yield while obeying the policy and convention that is set by the government. [5]

a. It is necessary to comply with various national, status and local regulations

b. It is essential to make available goods and services that at least meet minimum legal Requirements

c. It is very important that a winning company be defined as one that fulfils its legal obligations is time after time money-spinning

\subsection{Ethical Responsibility}

The above figure (i.e. Figure 1) marks societal beliefs of "good behavior as ethical responsibilities." companies, according to Carroll, must observe ethical standards when operating. This may be such as appropriate overtime remuneration for long hours or an "unofficial" punch-out time. Ethical responsibilities are voids in the legal system and allow companies to act with humanitarian values in mind. Even though ethical responsibility is the next outside layer in Carroll's CSR pyramid, it must be "without fail recognized that it is in dynamic interplay with the legal responsibility class". It is in other words pushing the legal responsibilities to broaden at the same time as expecting businesses to activate at a level above that is required by law [5].

a. It is significant to act upon in an approach consistent with expectations of societal customs and ethical norms

b. It is important to put off ethical norms from being compromised in order to attain corporate goals

c. It is important that exceptional corporate citizenship be defined as doing what is expected morally or ethically

d. It is central to be familiar with that corporate integrity and ethical behavior go beyond mere compliance with laws and regulations

\subsection{Philanthropic Responsibility}

Philanthropic responsibilities are voluntary obligations a corporation takes on. These responsibilities are over and above ethical considerations. They may include charity runs or setting up "day-care" centers within the office. Philanthropic responsibility (i.e. figure 1) refers to corporations acting as a good corporate citizen, by contributing resources to the community and improves quality of life. The distinction between ethical and philanthropic is that the philanthropic one is not expected in an ethical or moral sense. It is good if businesses give away charities, but they are not seen as unethical corporations if they aren't engaged in those kind of activities.

a. It is essential to carry out in a manner consistent with the philanthropic and charitable expectations of society

b. It is vital that managers and employees participate in charitable and benevolent activities within their local communities.

c. It is significant to voluntarily lend a hand those projects that augment a community's "quality of life."

d. The pyramid declares the dissimilar apparatus that mutually constitute the whole. Even though the responsibilities have been explained and treated 
separately, they are not mutually exclusive

\section{The Responsibilities of Unilever Bangladesh Ltd (UBL) in the Perception of the Carroll's CSR Pyramid}

\subsection{Economic Responsibility}

Businesses have a responsibility not to just make money, but also to have a positive way on the environment they run in and the people they affect. In a challenging and competitive marketplace, the UBL must maintain a dynamic balance between the short and the long-term needs of their business and their stakeholders. So the economic dimension of UBL 's maneuvers must be given full value in relation to the position it performs vis-à-vis all its stakeholders, carefully monitoring the value assembly process and reporting on this progression in a way which is crystal clear.

As a result, UBL have to responsible to generate profit for its shareholders, but not at the expense of the environment or people. UBL had to have an essence of long-term survival through profit without neglecting ethics and the interest of its stakeholders.

\subsection{Legal Responsibility}

Unilever requires to obey with the laws and regulations of the countries in which it operates. Unilever does not give or receive, whether directly or indirectly, bribes or other improper advantages for business or financial gain. No employee may offer, give or receive any gift or payment which is, or may be construed as being, a bribe. Any demand for, or offer of, a bribe must be rejected immediately and reported to management. Unilever accounting records and supporting documents must accurately describe and reflect the nature of the underlying transactions. No undisclosed or unrecorded account, fund or asset will be established or maintained. Our Code of Business Principles describes the operational standards that everyone at Unilever follows. It also supports our approach to governance and corporate responsibility. We conduct our operations with honesty, integrity and openness, and with respect for the human rights and interests of our employees. We shall similarly respect the legitimate interests of those with whom we have relationships. The legal responsibility also means that the UBL publishes complete and accurate financial statements and descriptions of their business, neither miss-stating material facts nor falling to disclose facts which might be material to potential investors. The company's financial record, including time sheets, sales record and expenses reports, must be accurate, timely and in accordance with the law. These records are the basis for managing the company's business and for fulfilling its obligation to shareholders, employees, customers, suppliers and regulatory authorities.

\subsection{Ethical Responsibility}

Ethical responsibility could refer to a range of issues from choosing the right ingredient or package, how suppliers are being paid, how they test their products and building programs for fair trade, but also to financially support NGOs and human rights organizations like the Red Cross. For this reason, Unilever was named the world's most ethical company in 2009. A think tank was dedicated to ranking the top ethical businesses on business ethics, corporate social responsibility, and anti-corruption and sustainability. Unilever's website explains, "According to the judges, Unilever earned a coveted place on the list by going beyond legal minimums, introducing innovative ideas to benefit the public and forcing its competitors to follow suit by raising the bar on what it takes to be an ethical leader." Unilever has been a true standout in the industry proving good practices result in a good image. In 2007 Patrick Cescau, Unilever's chief executive, was awarded the Botwinick Prize in Ethics by the Columbia Business School. The award is given to an individual who represents the highest standard of professional and ethical conduct. After receiving the award, Mr. Cescau explained, "Social responsibility and sustainable development are no longer fringe activities, but are central to our business. And just as this has become core to business, so it should also become core to management education. It must be moved to the heart of the curriculum."Also in 2007, the Carbon Disclosure Project considered Unilever best in its class in dealing with climate change disclosure. It was also, for nine years running, the leader in the Dow Jones Sustainability World Indexes in the food and beverage sector. Additionally, playing a large role in the tea industry, Unilever decided to partner with the Rainforest Alliance. They promised to obtain all of their tea products from sustainable, ethical sources. The UBL also is an active member of the Ethical Trade Initiative (ETI) and has adopted the ETI Base code purchasing products only from suppliers that meet ethical trade standards where employment is freely chosen, working conditions are safe and hygienic, child labor is not used, working hours are not excessive, living wages are paid, freedom of association and the right to collective bargaining are respected, no harsh or inhumane treatment is allowed and no discrimination is practiced. In order to make sure that all suppliers meet the ETI standards, they are obliged to sign a contract agreeing to hold on to the standards and to undertake regular ethical assessment. They have furthermore established an Ethical Trade and Community Trade program "to help create livelihood, and to explore tradebased approaches to supporting sustainable development by sourcing ingredients and accessories direct from socially and environmentally marginalized producer communities". Community trade refers to trade that is based on a long term relationship with communities by helping them to sell their product and be independent. The ethical trade program conforms to high levels of labor standards, including the avoidance of child labor, forced labor, sweatshops, adverse health and safety conditions, and violations of labor rights, or human rights. 


\subsection{Philanthropic Responsibility}

Unilever conducted their voluntary activities in three different segments. These are

a. Health-nutrition-hygiene

b. Education

c. Women Empowerment

In 2002 Unilever conducted some movement about health care and launched 'Lifebuoy Friendship Hospital' with a modified floating oil tanker. In 2006, Unilever sponsored a two months nursing training program with Ma O Shishu General Hospital in Chittagong and though they already sets up a modern operation theater and advanced intensive care unit in 25 May, 2004 for high quality medical care for economically deprived section of the society. Unilever launched a campaign named 'Annual Kalurghat Health Camp' to provide free health care facilities to people around Chittagong since 2007. In November 16, 2007 Unilever announced 'Pepsodent-Bangladesh Dental Society Oral Health Day'. Lifebuoy worked with NGOs, governments and other companies to introduce the 'Global Hand washing Day', launched on 15th October 2008 in many countries including Bangladesh. Unilever created Pepsodent Dentibus for giving free expert advice and dental checkup opportunities to the people and schoolchildren's. For building nations future Unilever emphasis on educational campaigns like working with an NGO named Shathee Samaj Kalyan Samity (SSKS) for giving education facilities for Banani residential slum areas children since January, 2005. Unilever volunteers also visit the school to show the importance of hygiene and health. The scholarship program by Fair and Lovely foundation was one such initiative that supported the dreams of talented women from economically disadvantaged families. In 2006, Unilever jointly funded 'Unilever Chevening Scholarship' for a Bangladeshi national wishing to study in a university in the United Kingdom with the cooperation of British council. For women empowerment Unilever was started pilot project 'Joyeeta' in August 2003, later on that leads to 'Project Aparajita' with CARE. Unilever also took some initiative like urban vocational training program in 2005 and scholarship program for women with FariaLata Foundation and UttoroneNari in 2003. Unilever in collaboration with Tengamara Mohila Shabuj Shanga (TMSS) started a tree plantation program on 30th October 2009 for promoting environmental care and awareness. Unilever made a huge positive impact to the mind of Bangladeshi people with their various campaigns of social works. By fair and lovely scholarship program 375 women got scholarship annually. Unilever are working with SSKS for giving study facility to 300 slum children. Over 10,000 people have cured by the Health camp out of which over 5000 ailing mothers and children received treatment and immunization, 4000 people received diabetic medical assistance and free blood tests and 6000 patients received free eye treatment which surgery facility and 500 indoor patients can be treated in the Ma O Shishu General Hospital in Chittagong and also 275000 people have been helped by the Life boy Friendship Hospital since 2001. Pepsodent Dentibushas reached 250,000 people per year with its facilities. Unilever are contributing in health sector, education, climatic problem and women empowerment and these are the most vital issues of nowadays society. So they created a positive atmosphere within general people especially rural people's mind that they are socially responsible and their product are environmental friendly. Unilever Bangladesh works with various NGO's; those are the helping hand of the poor people. As a leading company, their CSR activities are making positive perception about Unilever which is helping to create brand equity. These CSR activities are not only expressing their dedication for the society, but also to make their own place in the competitive market and stay the long time and create positive image about themselves. Their social activities are really appreciating. [7]

\section{The Responsibilities of SQUARE Bangladesh Ltd in Perception of the Carroll's CSR Pyramid}

\subsection{Economic Responsibility}

Square's Business Motivation is "Being Good by Doing Well" and to conduct transparent business operations based on market mechanism within the legal, ethical and social framework with aims to attain the mission reflected by their vision. They develop CSR activities to consider the interests of their external and internal stakeholders (i.e., customers, employees, vendors, shareholders, society, government etc) along with the ecological and ethical considerations in all aspects of operations. Square is one of the pioneer signatories of United Nations Global Compact (UNGC) in Bangladesh. UNGC principles are aligned with company's culture from the very outset.

\subsection{Legal Responsibility}

Square recognizes that progressive labor policies are good business practices; especially for a company like that has global ambition. They follow laws and encourage work environment that welcomes diversity and also follow nondiscrimination and fair treatment policy both in the recruitment and selection process and performance management system. They have Trade Union and their HR policies have been continuously up-to-dated as per existing labor laws of the country. They do not allow any female employees during night shift operations and strictly prohibit any form of forced labor. The company actively pursues the policy of no child labor in Square.

\subsection{Ethical Responsibility}

Transparency and Business Ethics is the core value of Square and it is strictly followed at every step of the business processes. Every business in Square is modeled in a way that enables the management to ensure highest degree of both 
financial and behavioral accountability. Square pursues Zero Tolerance policy against all kinds of corruption.

\subsection{Philanthropic Responsibility}

Square's activity goes well beyond the sphere of business. As socially conscious and responsible corporate body Square is committed to the improvement of the society as a whole. Meril-ProthomAlo festival sponsored by Square has become a national calendar event. Square helps many NGO's in their effort to make available healthcare to the disadvantage population of the country. It sponsors programs to build awareness on the healthcare need. Square is also a major sponsor of sporting events in the country.

\section{Comparison of the Corporate Social Responsibility (CSR) of the Studied Companies}

\subsection{Economic Responsibility}

Unilever emphasizes that there is more to life than making money. It has to responsible to generate profit for its shareholders, but not at the expense of the environment or people. They strongly believe triple bottom line: people, profit and planet. Square emphasize profits with ethical values and sustainable development i.e. Profits are made through integrating the companies' values into their day to day operations. So it can be said that both want to achieve profit but Unilever Bangladesh Ltd making profit by emphasizing on triple bottom line, on the other side Square making profit by considering their own ethical values and shareholders interest. They allwant to long term survive through profit by ethical behavior and triple bottom line to add economic expansion by humanizing the quality of life of the local people, society and the whole globe at large.

\subsection{Legal Responsibility}

Legal responsibility is like a wrestling stage which every company has to face. Square follow laws and give confidence work atmosphere that welcomes diversity and also follow non-discrimination and fair treatment policy both in the recruitment and selection process and performance management system.

On the other side, Unilever Bangladesh Ltd believes its own Code of Business Principles which suggests the operational standards that everyone should follow at Unilever. However this responsibility do not assure that they are the good corporate citizen who perfectly obey the law. They just make sure that their suppliers, partners and employees satisfaction based on legal responsibility. But they are not anxious about ISO 9001:2000 which suggest specifies requirements for a quality management system where a company needs to show its capability to consistently provide product that meets customer and applicable regulatory requirements, and aims to boost customer satisfaction through the effective application of the system, including processes for continual improvement of the system and the assurance of conformity to customer and applicable regulatory requirements.

\subsection{Ethical Responsibility}

Business and organizations do not operate in a vacuum. Their relationship to the society and environment in which they operate is a critical factor in their ability to continue to operate effectively. It is also increasingly being used as a measure of their overall performance. ISO 26000 provides guidance on how businesses and organizations can operate in a socially responsible way. This means acting in an ethical and transparent way that contributes to the health and welfare of the society.

In this regard, Unilever Bangladesh Ltd uses their influence to help raise the quality of life and standards of living by doing business in a responsible and sustainable way. Unilever Bangladesh Ltd has always been very successful in achieving their ethical values where Square is working towards that direction. Square manly refers to their ethical responsibility being transparence and follow their own business ethics.

\subsection{Philanthropic Responsibility}

The main philanthropic activity of Unilever Bangladesh Ltd is to protect our universe any way and the steps which they take to create a better world. Unilever Bangladesh Ltd believe that every employee has right to get healthy working environment; First aid if any accident occur. Stop abuse of human rights, do not take any harmful experiment on animals. There is a philosophic believe that an educated nation can reach that apex where ever or never is not possible to think for uneducated nation. That's why Unilever Bangladesh Ltd considers education as a philanthropic responsibility. Finally they emphasize on women empowerment. Unilever Bangladesh Ltd said that donating some money for charitable purpose is not a part of CSR; CSR means the combination of health-nutrition-hygiene, education and women empowerment. On the other side, Square refers their philanthropic responsibility in the social sector. Sponsoring money for MerilProthomAlo, helps different NGO's for overall country development, aware people to take one child policy in different way and like that. So it is clear that, their major philanthropic activity mainly social welfare, in brief, Square want to bear good corporate title to do social activity.

\section{Findings of the Study}

From the above analysis it has been observed that both of the companies consider CSR as investment not as expense. They also agree that CSR reflects acting as a good corporate citizen, being ethical, obeying the law and being profitable. Both Companies state that business target is achieved through responsible and sustainable behavior which itself create value for their customers. It has also been found that the said companies use their influence to help raise the 
quality of life and standards of living by doing business in a responsible and sustainable way.

The Unilever Bangladesh Ltd has always been very successful in achieving their ethical values where Square is working towards that direction. The Unilever Bangladesh Ltd emphasize that there is more to life than making money. It strongly believes on triple bottom line; people, profit and planet. The study represents that both want to long term survival through profit by ethical behavior and contribute to economic development by humanizing the quality of life of the local people and society at large.

\section{Conclusions}

Corporate Social Responsibility (CSR) is about achieving corporate reputation in ways that honor ethical values, respect local people, and protect natural environment. According to Carroll's Pyramid of CSR, Unilever Bangladesh Ltd is more emphasized more on triple bottom line: people, profit and planet. They take philanthropic activities to increase customer royalty which indirectly generate corporate profit. Their business objective is to be a good corporate citizen locally as well as globally. On the other hand, Square also walks same row, but they take their CSR responsibility to develop their own local community, region and national economy. If Unilever Bangladesh Ltd wants to wear CSR title then it has to overcome a tough mountain and through this difficult way Unilever Bangladesh Ltd has just stayed in the midway. On the other hand Square has just started to think about CSR.

\section{References}

[1] Alimullah, M., (2006), Dynamics of Corporate Social Responsibility - Bangladesh Context.

[2] Green Paper on CSR, Asia Link Program, The European Union.

[3] David Crowther, Güler Aras (2008)- Corporate Social Responsibility.

[4] Friedman, M. (1970). The social responsibility of business is to increase its profits. NY Times Magazine, 13 September, pp. 32-33, 122, 124, 126.

[5] Carroll, A. B., (1979), A three-dimensional conceptual model of corporate social performance. Academy of Management Review 4 (4), 496-503.

[6] Porag, R. S., (2014), Corporate Social Responsibility in Bangladesh: Practice and Perpetuity.

[7] J. Mustafa "Unilever CSR activity in Bangladesh 2000-2009”.

[8] Belal, A. T., (2001), A study of corporate social disclosures in Bangladesh. Management Auditing Journal 16 (5), 274-289.

[9] Mohan A., (2006), Global corporate social responsibilities management in MNCs, Journal of Business Strategies, Huntsville: Vol. 23, Iss. 1, 9, 24).

[10] Friedman, M. (1970). The social responsibility of business is to increase its profits. NY Times Magazine, 13 September, pp. 32-33, 122, 124, 126.

[11] Porag, R. S., (2014), Corporate Social Responsibility in Bangladesh: Practice and Perpetuity.

[12] Mondol E. P., (2009), Why Corporate Social Responsibility? The Context of Bangladesh, Journal of Ammado Foundation, and Online version viewed on 20 Jul 2009 15:05 GMT. 